\title{
A new species of anole lizard, genus Norops (Squamata: Polychrotidae), from the Cordillera de Talamanca, Costa Rica
}

Jay M. Savage' and Craig Guyer ${ }^{2}$

1 Department of Biology, University of Miami. Box 249118 Coral Galbes, Florida 33124-0421, USA; fax 305284 3973, jsavage@fig.cox.miami.edu

2 Department of Zoology and Wildlife, Auburn University, Auburn, Alabama, 36849-5414, USA.

Received 10-IX-1997. Corrected 2-IV-1998. Accepted 15-IV-1998.

\begin{abstract}
A new species of anole lizard of the Norops fuscoauratus group is described from the southem Cordillera de Talamanca of Costa Rica. It differs from allied species from Costa Rica (Norops altae) and southwestem Panama (Norops exsul, $N$. fortunensis and N. kemptoni) primarily by having the male dewlap extending to the level of the axilla and being pink with a orange anterior margin. It also has longer legs than $N$. fortunensis and $N$. kemptoni and differs from the latter, $N$. altae and $N$. exsul in having 2-4 slightly enlarged middorsal scale rows. The new form is known only from Cerro Pando on the border between Costa Rica and Panama.
\end{abstract}

Key words: Reptilia, Squamata, Polychrotidae, Norops, Costa Rica.

During a preliminary survey of the herpetofauna of the La Amistad Biosphere Reserve in 1990, specimens of an undescribed anole (genus Norops) were collected by Karen R. Lips and the junior author. Initially in the field it was confused with the smaller Norops altae (Dunn, 1930) because of similarities in head shape and body coloration. Subsequently, Lips collected additional material in 1991-1992 that confirmed the species distinctiveness from $N$. altae. Three allied taxa, Norops kemptoni (Dunn, 1940) and the recently described Norops exsul (Arosemena and Ibañez, 1994) and Norops fortunensis (Arosemena and Ibañez, 1993) are known from southwestern Panama but differences in male dewlap color and other features distinguish the new form from these species as well. In allusion to the occurrence of the new form on the slopes of Cerro Pando on the border between Panama and Costa Rica, it is called:

Norops pandoensis, sp. nov.

Holotype: Costa Rican Expeditions (CRE) collection 5290, an adult male; collected by Karen R. Lips, September 21, 1991, from Costa Rica: Puntarenas Province: Cantón Coto Brus: Zona Protectora Las Tablas: La Changuinolita $1950 \mathrm{~m}$.

Paratypes: Costa Rica: Puntarenas Province: Cantón Coto Brus: Finca Las Tablas, 1600 m (CRE 5180, 5181); La Changuinolita, $1950 \mathrm{~m}$ (CRE 5291, 5321); nr. La Changuinolita, 1850-1950 m (CRE 5295, 5318, 5329). 
Diagnosis: A small, yellowish-tan, shortlegged member of the Norops fuscoauratus species group characterized by having enlarged postcloacals and a large, bicolored pink and orange dewlap in males and a small, plain dewlap not contrasting in color with the rest of the throat in females.

General Morphology Head: Head scales moderate in size, keeled at tip of snout, smooth or rugose throughout rest of head except for supraocular semicircles and canthals. 8-10 scales separate second canthals across top of head, these forming a distinct dish posteriorly. Usually 1 (occasionally 2) scale between rostral and anterior nasal. Usually 2 (occasionally 1) scale rows between supraocular semicircles. One greatly enlarged superciliary followed by 1 2 smaller superciliaries, the latter $>2$ times larger than lateral granules. Canthus distinct, formed by 5-6 enlarged keeled scales. 6-8 loreal scales between posterior canthals, these pustulose; the row above the supralabials $>2$ times size of other loreals. Temporals granular, enlarging and flattening gradually in supratemporal region. Interparietal large, flat, plate-like; 2-3 scales between interparietal and supraocular semicircles. Suboculars in contact with supralabials. 6-8 (usually 7) sublabials to level of center of eye.

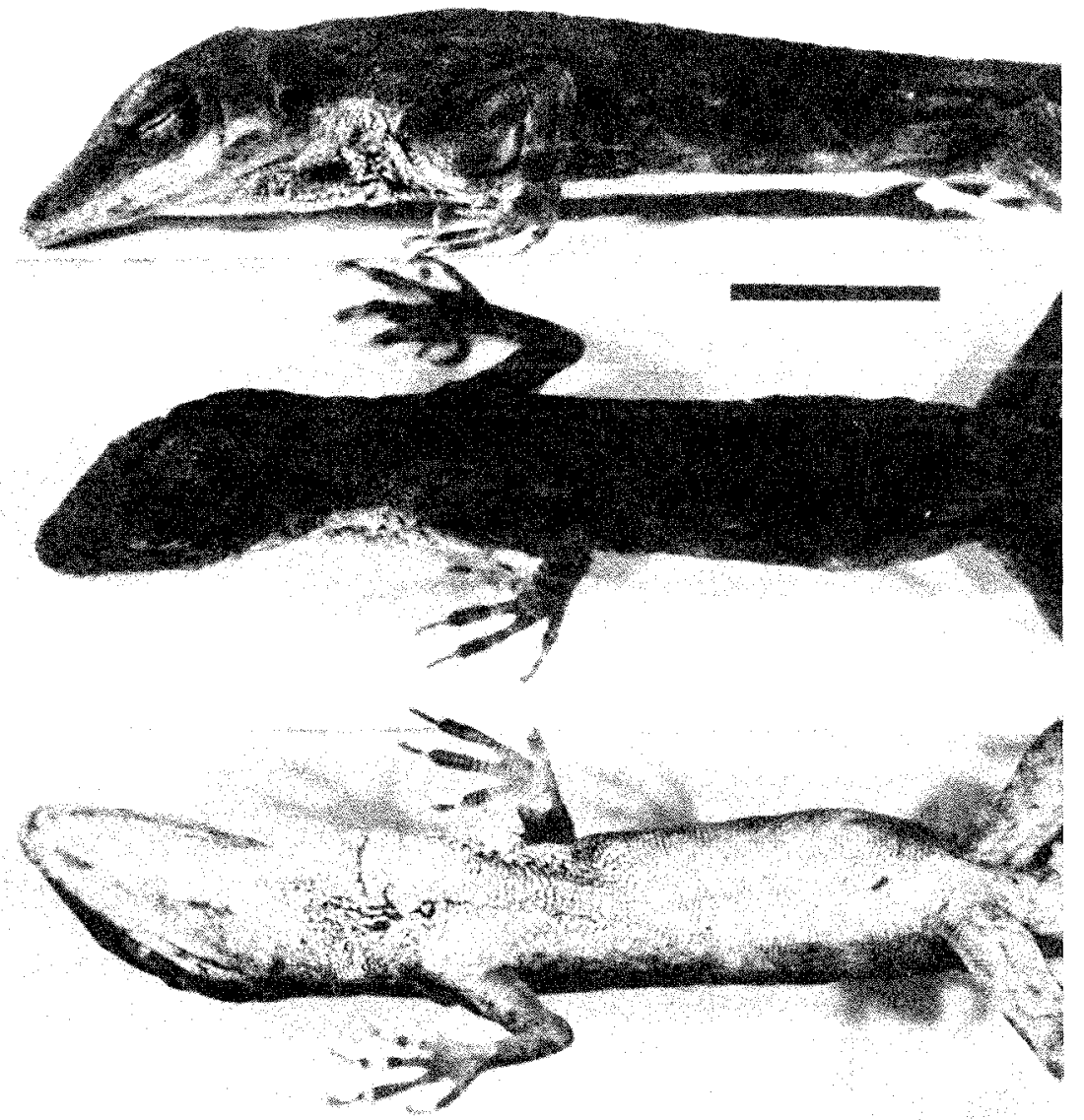

Fig. 1. Views of head and anterior body of holotype (CRE 5290) of Norops pandoensis, new species; above: lateral view, middle: dorsal view, below: ventral view. Scale bar $1 \mathrm{~cm}$. 
Mentals wider than deep. Sublabials $\geq 2$ times size of gulars. Transition between sublabials and gul ars abrupt. Male dewlap large, extending well posterior to level of axilla; small, plain, white dewlap present in females.

Trunk: 2-4 middorsal scales about twice size of granular lateral scales; transition between these regions gradual. Dorsalmost scales very weakly keeled and weakly imbricate. Ventral scales smooth (occasionally very weakly keeled) and weakly imbricate.
Dorsum usually tan-yellow but changing to darker colors, olive-green to dark brown when captured. Darker oblique lateral bars on flanks may be present. One female with a broad middorsal light tan stripe bordered laterally by dark brown area that fades to light tan from head to tip of tail and laterally. Another female had a less distinct middorsal lighter brown stripe with a series of elongate, rectangular dark brown markings down the midline from the neck to the base of the tail. Supra- and infralabials white to pale yellow.

TABLE 1

Characteristics that differentiate Norops pandoensis from similar species from lower Central America.

\begin{tabular}{|c|c|c|c|c|c|}
\hline & pandoensis & altae & exul & fortunensis & kem ptoni \\
\hline SL adult males & $49.5-53$ & $32-52$ & $39-47$ & 48 & $44-53$ \\
\hline adult females & $49-60$ & $39-47$ & 46 & - & $46-54$ \\
\hline Adpressed leg to & ear & ear & ear & $\begin{array}{c}\text { between } \\
\text { shoulder and ear }\end{array}$ & shoulder \\
\hline $\begin{array}{l}\text { Scales between } \\
\text { supraocular semicircles }\end{array}$ & $\begin{array}{c}1-2 \\
\text { usually } 2\end{array}$ & $\begin{array}{c}1-2 \\
\text { usually } 1\end{array}$ & 2 & 3 & 1 \\
\hline $\begin{array}{l}\text { Slightly enlarged rows } \\
\text { of dorsals }\end{array}$ & $2-4$ & 0 & 0 & $2-4$ & 0 \\
\hline $\begin{array}{l}\text { Enlarged postcloacals } \\
\text { in males }\end{array}$ & present & absent & absent & present & absent \\
\hline Extent of male dewlap & chest & $\begin{array}{c}\text { just } \\
\text { posterior to arm } \\
\text { insertion }\end{array}$ & chest & $\begin{array}{l}\text { middle } \\
\text { venter }\end{array}$ & chest \\
\hline Dewlap in females & plain white & absent & plain white & - & absent \\
\hline Dewlap color in males & $\begin{array}{l}\text { pink, anterior } \\
\text { margin orange }\end{array}$ & $\begin{array}{l}\text { orange, } \\
\text { margin } \\
\text { yellow }\end{array}$ & $\begin{array}{c}\text { orange, } \\
\text { margin } \\
\text { cherry-red }\end{array}$ & $\begin{array}{l}\text { reddish } \\
\text { orange, } \\
\text { margin red }\end{array}$ & $\begin{array}{l}\text { red, orange } \\
\text { spot on } \\
\text { anterior } \\
\text { margin }\end{array}$ \\
\hline $\begin{array}{l}\text { Color of enlarged dewlap } \\
\text { scales }\end{array}$ & white & white & yellow & yellow & white \\
\hline Distribution & Costa Rica & Costa Rica & W. Panama & W. Panama & W. Panama \\
\hline
\end{tabular}

Limbs and Digits: Hind legs short; fourth toe of adpressed hind limb reaching level of tympanum. Supradigital scales weakly multicarinate. 31-32 lamellae under 4th toe; 15 to 16 lamellae under phalanges $\mathrm{ii}+$ iii.

Tail: Scales at middorsum and midventer of tail slightly ( $<2$ times) larger than lateral scales and strongly keeled. Tail laterally compressed. Enlarged postcloacal scales in males.

Coloration in Life: Apparently having some ability for color change or with a greenish cast.
Dewlap in males mostly pink, anterior one-fourth orange, scales white; plain white in females. Venter white to yellow-white, immaculate or suffused with brown laterally. Iris orange-red.

In Preservative: Generally tan dorsally with darker markings more evident. The parietal peritoneum is black.

Measurements: Total length to $144 \mathrm{~mm}$; males $49.5-53 \mathrm{~mm}$ in standard length, females $49-60 \mathrm{~mm}$; tail length divided by standard length $1.7-2.0$, in adu ts. 
Habitat: This diurnal species is found in the herbaceous and low shrub zone (up to $1.5 \mathrm{~m}$ ) in Lower Montane Rainforest (Holdrige, 1967; Tosi, 1969).

Comparisons: $N$. pandoensis is a member of the fuscoauratus species group. Lizards of this group are small to moderate in size, have small head scales, small dorsal scales, mostly smooth ventrals, long tails that are round to subcylindrical in cross-section. Members of this group usually have an inscriptional rib formula of 3: 1 (Etheridge, 1965) as is the case with $N$. pandoensis.

Among Central American members of the fuscoauratus group the new species is unlikely to be confused with Norops limifrons (including $N$. biscutiger) or Norops polylepis both of which have long legs, i.e., the tip of the 4th toe reaches beyond the orbit when the leg is adpressed along the side of the body. In addition, the dewlap in male $N$. limifrons is white with a basal yellow to orange spot and is uniform orange in male $N$. polylepis.

Among short-legged members of the fuscoauratus group, $N$. pandoensis can be distinguished immediately from the lowland Norops carpenteri which is green, smaller (standard length $35-45 \mathrm{~mm}$ ) and with a uniform orange dewlap color in males. Comparisons with the four short-legged species most similar to $N$.

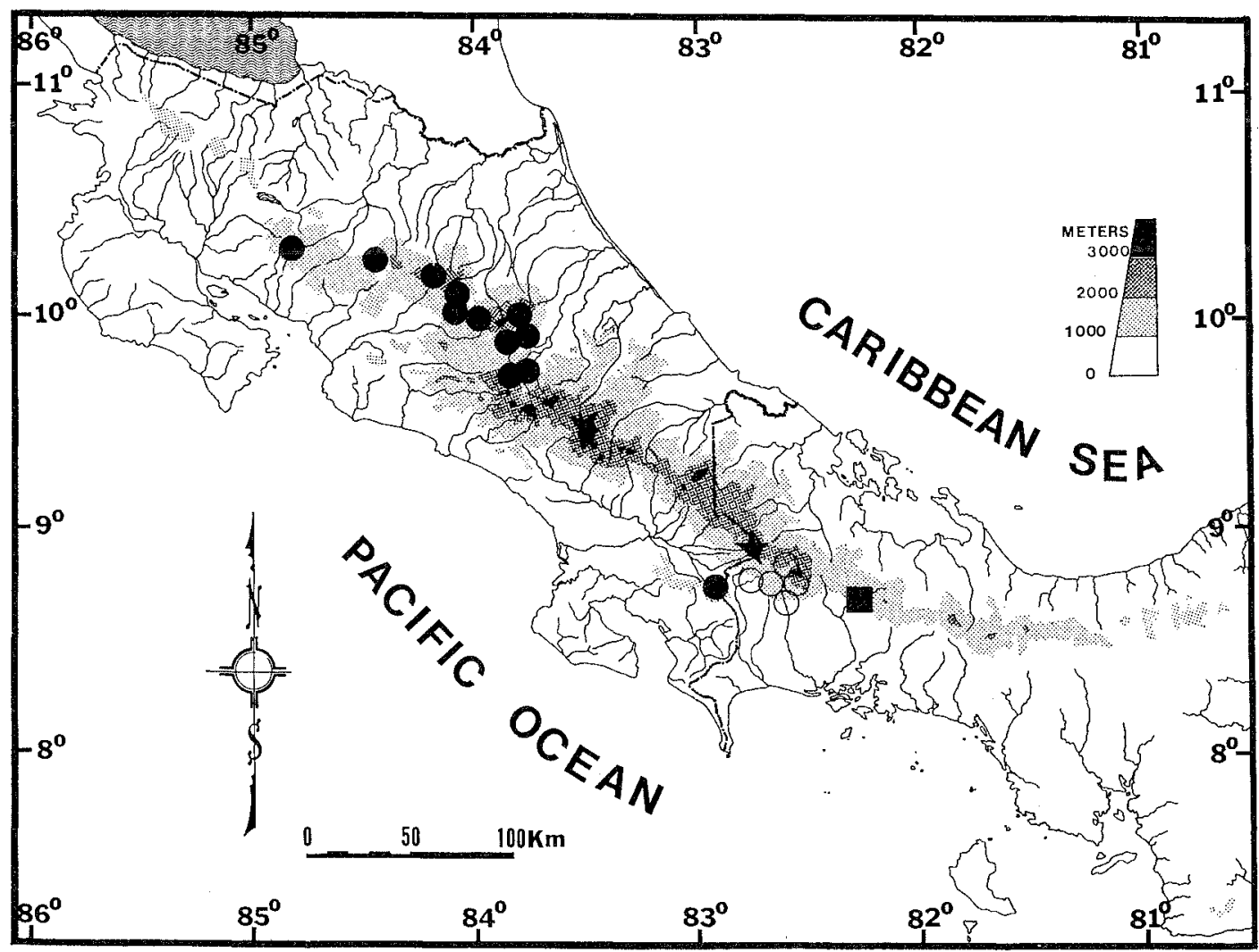

Fig 2. Distribution of montane shor-legged Norops of the fuscoauratus group in Costa Rica and western Panama. N. altae (closed circles); $N$. exsul and $N$. fortunensis (square); $N$. kemptoni (open circles); $N$. pandoensis (star). One symbol may represent several adjacent localities. 
pandoensis in general appearance are summarized in Table 1. All are upland forms and one or more of them may prove to occur sympatrically with $N$. pandoensis.

\section{ACKNOWLEDGMENTS}

Karen R. Lips, St. Lawrence University, collected most of the type series and generously make available her fieldnotes on the new taxon. Juan Diego Alfaro of the Servicio de Parques Nacional of Costa Rica, arranged for necessary permits and aided study of the Biosphere Reserve in many other ways. Bruce E. Grayson prepared the photographs for Fig. 1.

\section{RESUMEN}

Se describe una especie nueva de lagartija del grupo de Norops fuscoauratus de Talamanca, Costa Rica. Difiere de las especies emparentadas de Costa Rica (Norops altae) y Panamá (Norops exsul, $N$. fortunensis y N. kemptoni) básicamente porque una estructura masculina ("dewlap") se extiende hasta el nivel de la axila y por ser rosado con un margen exterior anaranjado. También tiene patas más largas que $N$. fortunensis y $N$. kemptoni; difiere de este último y de $N$. altae y $N$. exsul en que tiene 2-4 filas ligeramente agrandadas de escamas medio-dorsales La especie nueva solo se conoce de Cerro Pando (frontera entre Costa Rica y Panamá).

\section{REFERENCES}

Arosemena, F. A. \& R. Ibañez. 1993. Una especie nueva de Anolis (Squamata: Iguanidae) del grupo fuscoauratus de Fortuna, Panamá. Rev. Biol. Trop. 41: 267-272.

Arosemena, F. A. \& R. Ibañez. 1994. Un sauio nuevo del genero Anolis (Reptilia, Polychrotidae), grupo fuscoauratus, de las tierras altas de Chiriquí, Panamá. Carib. J. Sci. 30: 222-227.

Dunn, E. R. 1930. Notes on Central American Anolis. Proc. New Engl. Zool. Club 12: 15-24.

Dunn, E. R. 1940. New and noteworthy herpetological material from Panama. Proc. Acad. Nat. Sci. Phila. 92: 105-122.

Etheridge, R. E. 1965. The abdominal skeletons of lizards in the family Iguanidae. Herpetologica 21: 161-168.

Holdrige, L. R. 1967. Life zone ecology. Tropical Science Center, San José, Costa Rica. 206 p.

Tosi, J. A., Jr. 1969. Mapa ecológico, República de Costa Rica. Tropical Science Center, San José, Costa Rica. 